\title{
How Low can Creatinine Clearance Go, and Yet Life Remains Sustained in Elderly?
}

\section{Edward Bourry $^{1^{\star}}$, Florence Maleplate ${ }^{2}$, Maan Youssef ${ }^{1}$, Jean Jacques Montseny ${ }^{1}$ and Martine Merceron ${ }^{2}$}

${ }^{1}$ Department of Nephrology, Pontoise Central Hospital, Pontoise, France

${ }^{2}$ Department of Geriatrics, Pontoise Central Hospital, Pontoise, France

\begin{abstract}
We came across a somewhat peculiar case of terminal renal insufficiency in an elderly lady. We believe this case illustrates well the difficulties that a clinician faces on daily basis regarding the evaluation of glomerular filtration rate building on serum Creatinine level measurement alone. We have witnessed a creatinine clearance plunging till less than $2 \mathrm{ml} / \mathrm{min}$ without real need for renal replacement therapy. We have performed a Cystatine c serum level measurement for comparison.
\end{abstract}

Keywords: Creatinine clearance; Cystatine clearance in elderly

\section{Introduction}

We came across a somewhat peculiar case of terminal renal insufficiency in an elderly lady. We believe this case illustrates well the difficulties that a clinician faces on daily basis regarding the evaluation of glomerular filtration rate building on serum creatinine level measurement alone.

\section{Case Presentation}

An 89 years old lady was admitted in late November 2013. She weighed $81 \mathrm{~kg}$ for $1.56 \mathrm{~m}$ of height. Her body mass index was $33 \mathrm{~kg} / \mathrm{m}^{2}$. Her past medical history was notable for: Insulin dependant diabetes mellitus, Hypertension, Hypothyroidism substituted by thyroxin, and an already advanced chronic renal insufficiency thought to be secondary to a diabetic and hypertensive nephropathy. The lady was admitted to the hospice in December 2013 with the advanced directives accepted by her nephrology and geriatric specialist as not to start dialysis or any other renal substitution therapy in case her renal function got worse. Her medication list contained 7 medications including: Insulin, B-Blocker, anti depressant of Selective serotonin reuptake inhibitors family (Venlafaxine), calcium and vitamin D supplements in addition to Thyroxin supplementation for known Hypothyroidism. The patient was particularly incompliant to thyroxine supplements and hence was clearly hypothyroid at some point as Thyroid stimulating hormone level proves it (Table 1). She maintained a good general condition, appetite and maintained a good level of activity with relative autonomy (walk, dress alone and eat with fellow hospice residents) till one week before her death on the 28th of may 2014 . We have witnessed a creatinine clearance plunging till less than $2 \mathrm{ml} / \mathrm{min}$ without real need for renal replacement therapy. We have performed a Cystatine $\mathrm{c}$ serum level measurement for comparison. While Cystatine-C based clearance using the simple Cystatine-C formula was higher than more standard Chronic Kidney Disease-Epidemiology Collaboration (CKD-EPI) clearance level, combining both formulas as prone by some authorities in Nephrology

\section{Discussion}

Creatinine clearance calculated based on validated formulas are known to perform poorly in the extremes of age. Serum Cystatin-C based formulas are not yet standard of practice, yet were said to better perform in the elderly [1]. At one point, for our patient, simple Cystatin-C formula showed higher clearance $(6 \mathrm{ml} / \mathrm{min} \mathrm{Vs} 2 \mathrm{ml} /$ min using the CKD-EPI formula) we cannot tell whether combining both measurements approached better the true clearance [2] Hypothyroidism is the most frequent thyroid abnormality associated with chronic Kidney disease [3] (CKD). Indeed, in our patient, the refusal to take thyroxin was the main reason behind the high level TSH present in this case. It is also known that Uremia tends to diminish the TSH levels through the blunting of the anterior pituitary response to the Thyroid releasing hormone originating in the anterior hypothalamus. Such profound hypothyroidism with resulting lower metabolic rate may preserve, we believe, patient's wellbeing despite a very low clearance. While it is not clearly stated in the medical literature the minimal clearance necessary to sustain life, we believe our patient performed quiet well despite a creatinine clearance as low as $2 \mathrm{ml} / \mathrm{min}$. The patient's will, as described in her advanced directives, was respected and no renal substitution was started despite very high urea levels.

\begin{tabular}{|l|c|c|c|c|}
\hline & $\mathbf{1 2 . 2 0 1 3}$ & $\mathbf{4 . 2 0 1 4}$ & $\mathbf{5 . 2 0 1 4}$ & $\mathbf{2 1 . 0 5 . 2 0 1 4}$ \\
\hline $\begin{array}{l}\text { Serum } \\
\text { Creatinine }(\mu \mathrm{mol} / \mathrm{l})\end{array}$ & 339 & 722 & 1167 & 1520 \\
\hline $\begin{array}{l}\text { Serum Urea } \\
\text { (mmol/l) }\end{array}$ & 31.5 & 40.8 & 52.7 & 73.1 \\
\hline $\begin{array}{l}\text { CKD-EPI creat } \\
\text { clearance ml/min }\end{array}$ & 10 & 4 & 2 & 2 \\
\hline $\begin{array}{l}\text { Serum Cystatin } \\
\text { c mg/l }\end{array}$ & & & 5.99 & \\
\hline $\begin{array}{l}\text { Cystatine } \\
\text { clearance }\end{array}$ & 8.62 & & $49.37 \mathrm{mUI} / \mathrm{L}$ & \\
\hline \begin{tabular}{l} 
TSH en mlU/L \\
\hline $\begin{array}{l}\text { CKD-EPI } \\
\text { Cystatin- } \\
\text { Creatinine } \\
\text { clearance }\end{array}$
\end{tabular} & & 3 & \\
\hline
\end{tabular}

Table 1: Summary of Important Laboratory Results.

*Corresponding author: : Edward Bourry, Consultant, Department of Nephrology, Pontoise Central Hospital, 6 Avenue lle de France, Pontoise 95300, France, Tel: +33668446961; E-mail:edouard.bourry@gmail.com

Received: February 21, 2015; Accepted: March 20, 2015; Published: March 27 2015

Citation: Bourry E, Maleplate F, Youssef M, Montseny JJ, Merceron M (2015) How Low Can Creatinine Clearance Go, and Yet Life Remains Sustained in Elderly? J Nephrol Ther 5: 197. doi:10.4172/2161-0959.1000197

Copyright: ( $) 2015$ Bourry E, et al. This is an open-access article distributed under the terms of the Creative Commons Attribution License, which permits unrestricted use, distribution, and reproduction in any medium, provided the original author and source are credited. 
Citation: Bourry E, Maleplate F, Youssef M, Montseny JJ, Merceron M (2015) How Low can Creatinine Clearance Go, and Yet Life Remains Sustained in Elderly? J Nephrol Ther 5: 197. doi:10.4172/2161-0959.1000197

Page 2 of 2

More sophisticated direct measurements of glomerular filtration rate and clearance requiring 24 hours urine collection are quiet difficult to achieve particularly in the old age due to incontinence and compliance problems. Cystatin-C serum measurement and clearance calculation using the simple formula [2] may be a useful tool in this context.

\section{References}

1. Wasén E, Isoaho R, Mattila K, Vahlberg T, Kivelä SL, et al. (2003) Serum cystatin $C$ in the aged: relationships with health status. Am J Kidney Dis 42 : $36-43$.

2. Bevc S, Hojs R, Ekart R, Gorenjak M, Puklavec L (2011) Simple cystatin C formula compared to sophisticated CKD-EPI formulas for estimation of glomerular filtration rate in the elderly. Ther Apher Dial 15: 261-268.

3. Mohamedali M, Maddika RS, Vyas A, lyer V, Cheriyath P (2014) Thyroid disorders and chronic kidney disease. Int J Nephrol. 